\title{
Arctic Sustainability: The Predicament of Energy and Environmental Security
}

\author{
Erica M. Dingman *
}

Acquisition of Arctic hydrocarbon deposits is a strategic priority of Arctic states and numerous non-Arctic states alike. The U.S. Geological Survey estimates that the area north of the Arctic Circle holds 13 percent of undiscovered global oil reserves and 30 percent of undiscovered gas reserves, with the expectation that 84 percent of these reserves will be found offshore. Increasing global demand for energy, attributed primarily to population and income growth, alongside technical advancements and financial incentives will likely accelerate the rate at which stakeholders seek out these presumed Arctic hydrocarbons. ${ }^{1}$

Several non-state and state actors are concurrently pursuing a variety of means by which to reduce greenhouse gas emissions (GHG). From financial incentives and regulatory schemes aimed at increasing the development and instillation of renewable energy sources to persuasive articulations that address the detrimental effects of climate change, these stakeholders recognize that an everlasting thirst for non-renewable resources is a proposition lacking in long-term viability. Whereas large multilateral climate change agreements such as the Kyoto Protocol have been exceedingly difficult to get right, regionally-based networks of like-minded parties have achieved considerable success. Examples of such networks include the Inuit Circumpolar Council and the European Union, both of which have made significant contributions toward addressing the implications of hydrocarbon dependency, albeit from very different perspectives.

The Inuit Circumpolar Council (ICC) - a group representing the interests of Inuit from Canada, Denmark, Russia, and the United States - now grapples with the balance between preserving their homeland and the potential socioeconomic benefits of hydrocarbon extraction. Instead of focusing solely on extracting energy resources, the European Union (EU) is seeking to reduce region-wide GHG emissions, and is emphasizing

Erica Dingman is an Associate Fellow at the World Policy Institute based in New York City. Her research focuses on a broad spectrum of issues facing the Arctic in respect to climate change. From the geopolitical theater of Arctic stakeholders to interested non-Arctic parties the Arctic is increasingly the focus of government policy and international relations. In this context, Erica's research turns to the interconnection between climate change, hydrocarbon and mineral exploration, and the political participation of Inuit, one of the Arctic's indigenous groups. Previously she was a research associate at the Lower Manhattan Project funded by the U.S. Department of Energy. She holds a Masters in International Affairs from The New School.

1 According to the BP Energy Outlook 2030 report, demand for oil is on the decline while demand for conventional and unconventional gas is on the rise. However, non-fossil fuels, led by renewable energy sources, account for more than half the growth in energy demand. $B P$ Energy Outlook 2030 (London: British Petroleum, January 2011). 
renewable energy sources as a means of increasing energy independence and contributing to economic growth. ${ }^{2}$ Both the ICC and EU are on a quest to find solutions to difficult challenges, asking blunt questions that confront the status quo. Both the ICC and the EU seek a more influential voice in the outcome of Arctic strategy. The ICC is a Permanent Participant on the Arctic Council (AC), but unlike individual Arctic states the ICC does not have the right to vote. The EU is yet to have a voice at the $\mathrm{AC}$, and is seeking Permanent Observer status. Both have a strategic interest in accessing Arctic resources.

In considering the potential for Arctic hydrocarbons we must also consider the implications of development. Could the ICC and the EU act as a potential counterbalance to Arctic nations that have strong interests in hydrocarbon extraction?

As Simon Dalby has written, "The assumption that the environment is separate from both humanity and economic systems lies at the heart of the policy difficulties facing sustainable development and security thinking." ${ }^{3}$

\section{Environmental Challenges}

Climate change is the most significant global variable of the twenty-first century. According to Sheila Watt-Cloutier, former chair of the ICC, "The Arctic is serving as a canary in the coal mine for the global environment." ${ }^{4}$ Joey Comiso, senior scientist at NASA's Goddard Space Flight Center, claimed: "The sea ice is not only declining, the pace of the decline is becoming more drastic," a sign of a warming trend that will have ecological, socioeconomic, and security implications. ${ }^{5}$

Permafrost thaw damages existing infrastructure; commercial and residential buildings and bridges suffer severe damage or collapse; and ice-roads are compromised and railway tracks buckle. As permafrost becomes less stable, oil pipelines may shift, increasing the risk of oil spills. Commercial interests rely on the persistence of permafrost for transporting supplies to and from mines and drill sites. A 2011 UCLA study on the effects of Arctic warming reports that Northern Canada's famed TibbittContwoyto "diamond road," reportedly the world's most lucrative ice road, is expected to suffer the effects of permafrost thaw. ${ }^{6}$ For remote indigenous communities, compro-

2 European Commission, Climate Action: The EU Climate and Energy Package (last updated 18 October 2010); available at http://ec.europa.eu/clima/policies/package/index_en.htm.

3 Simon Dalby, "Security and Ecology in the Age of Globalization," Environmental Change and Security Project Report 8 (Summer 2002): 101.

4 Inuit Circumpolar Council Press Release, "Inuit of Canada Amongst the Hardest Hit by Climate Change," (30 August 2000); available at http://inuitcircumpolar.com/index.php?ID= $137 \&$ Lang $=$ En.

5 Patrick Lynch, “Arctic Sea Ice Continues Decline, Hits 2nd-Lowest Level," NASA News Feature (4 October 2011); available at http://www.nasa.gov/topics/earth/features/2011-icemin.html.

6 Scott R. Stephenson, Laurence C. Smith, and John A. Agnew, "Divergent Long-term Trajectories of Human Access to the Arctic," Nature Climate Change (29 May 2011): 156$60 ;$ available at www.nature.com/nclimate/journal/v1/n3/full/nclimate1120.html. 
mised winter roads could force communities "to switch to air cargo services, which will dramatically increase the costs of supplies," notes Scott Stephenson, lead author of the study.

Yet the study also noted that coastal communities would likely benefit from increased intercontinental shipping, and that Arctic coastal states will have greater access to their respective exclusive economic zones, including fisheries and hydrocarbons. Although states and corporate entities are the unquestionable beneficiaries of commercial activity, the extent to which indigenous communities will also reap the socioeconomic benefits remains questionable.

The accelerated erosion of Arctic shorelines further threatens vulnerable communities. The forced relocation of Alaskan Inuit villages is already a reality, creating what have been described as the first U.S. climate refugees. According to a 2004 U.S. Government Accountability Office report, four villages were in imminent danger as a result of flooding and soil erosion. By 2009, that number had risen to thirty-one villages, twelve of which decided to relocate. However, numerous complications have slowed the process, including the relocation costs of USD 95-200 million per village, the challenges in choosing a culturally acceptable location, and the trauma of uprooting families from generations of tradition. ${ }^{7}$

From an economic perspective the Arctic warming trend has potential consequences beyond those that have been observed thus far. Nicholas Stern of the London School of Economics noted that most scientific analysis is conservative in regard to long-term climate change forecasts. ${ }^{8}$ Until recently most Intergovernmental Panel on Climate Change (IPCC) models did not take into account the dangers posed by the melting permafrost. As a result, the far-reaching economic consequences of this aspect of global warming have not been taken into account.

Emerging pollutants also provide cause for alarm. An IPCC study suggests that melting permafrost will result in the release of megatons of carbon by the end of the century. ${ }^{9}$ Additionally, retreating sea ice is resulting in the reemergence of persistent organic pollutants (POPs) of declining levels. ${ }^{10}$ POPs are the result of industrial pollutants produced elsewhere, much of which settles in the Arctic region.

7 Tribes \& Climate Change, "Climate Change: Realities of Relocation for Alaska Native Villages"; available at www4.nau.edu/tribalclimatechange/tribes/ak_inupiaq_AkRelocation.asp.

Nicholas Stern, "Climate Change: The Economics of and Prospects for a Global Deal," video produced by the MIT Energy Initiative (19 November 2007); available at: http://mitworld.mit.edu/video/536.

9 Emily Chung, "Arctic Permafrost Thaw Will Boost Carbon Emissions," $C B C$ News: Technology and Science (15 August 2011); available at www.cbc.ca/news/technology/story/ 2011/08/15/science-carbon-sink-source-arctic.html.

10 Jianmin Ma, Hayley Hung, Chongguo Tian, and Roland Kallenborn, "Revolatilization of Persistent Organic Pollutants in the Arctic Induced by Climate Change," Nature Climate Change 1:5 (24 July 2011) 255-60; available at www.nature.com/nclimate/journal/v1/n5/ full/nclimate1 167.html?WT.ec_id=NCLIMATE-201108\#auth-4. 


\section{Oil Spills and Response}

The Arctic warming trend is also increasing the likelihood of access to potential hydrocarbon deposits, including access to deepwater oil drilling sites that are farther from shore. However, in the event of a hydrocarbon spill, this distance creates substantially more hazardous conditions for search and rescue missions (SAR) and clean-up responders. A likely rise in shipping activity and hydrocarbon extraction advances the inherent risk of oil spills and the environmental consequences, and the resulting loss to coastal communities would likely be long-lasting. A report by the U.S. National Oceanic and Atmospheric Administration (NOAA) reports that the 1989 Exxon Valdez spill dumped 11 million gallons of oil into Prince William Sound on the Alaskan coast. While Exxon claimed that the bulk of the clean up was completed in three years, the report indicates that decades later evidence of the spill is still present along the shores of Alaska, e.g., in a decline in the fish stock and contaminated mussel and clam stock. The Exxon Valdez spill occurred in relatively calm seas, conditions not standard in Arctic waters. ${ }^{11}$

In 2009 the Coastal Response Research Center at the University of New Hampshire gathered experts from government, NGOs, industry, and Arctic indigenous groups to consider the risks of increased hydrocarbon exploration and extraction activity in the Arctic. Scenarios considered "likely" to occur were assessed in order to evaluate the capability gaps of SAR missions and environmental recovery efforts. Numerous gaps surfaced, including inadequate fleets of rescue vessels; differing and incompatible national policies; poor communications infrastructure; out of date or incomplete environmental data; severe socioeconomic impacts to indigenous peoples; and environmental degradation. Less obvious gaps included language barriers; inadequate onshore resources to house and care for large groups of victims and SAR teams; governmental hesitation to act as a port of refuge for damaged vessels; and associated costs to government/governments responsible for SAR and clean up. ${ }^{12}$

Dr. Abdel Ghoneim, senior principal engineer for Det Norske Veritas, a risk management foundation focusing on the maritime oil, gas, and energy industry, notes: "We

11 United States Department of Commerce, National Oceanic and Atmospheric Administration, "NOAA's Office of Response and Restoration: Arctic Activities" (March 2009).

12 Coastal Response Research Center at the University of New Hampshire, Opening the Arctic Seas: Envisioning Disasters and Framing Solutions (Durham, NH: conference report issued January 2009; conference held 18-20 March 2008). Responsible parties are expected to bear the cleanup costs of oil spills. However, as the 2010 Deepwater Horizon spill in the Gulf of Mexico revealed, federal, state and local governments bore a substantial portion of the cost. Numerous factors contribute to determining which party will bear the cost for SAR and environmental recovery efforts. For instance, the U.S.-based Oil Spill Liability Trust Fund was established to pay certain oil spill costs. However, the Fund is capped at USD 1 billion per incident, and was at risk of reaching its limit as of 2010. For more information, see GAO-1190R Deepwater Horizon Oil Spill: Preliminary Assessment of Federal Financial Risks and Cost Reimbursement and Notification Policies and Procedures (Washingotn, D.C.: GAO, 12 November 2010). 
are not really prepared for a disaster [in the Arctic]." Although Ghoneim claims that the industry has the technology to develop deepwater drill sites, he also believes that regulators need to be more involved. Risk analysis and accident preparedness remain the top challenges for hydrocarbon companies operating in the Arctic. ${ }^{13}$ Admiral Robert Papp of the U.S. Coast Guard also expressed concern about the environmental implications of an Arctic oil spill. The agency "needs an appropriate level of Arctic pollution response. Presently we have none," he noted. ${ }^{14}$

\section{The Inuit Circumpolar Council and the European Union: Unusual Allies}

Is there potential for an ICC-EU alliance as a counterbalance to the commercial impetus for Arctic development? As stated earlier, both groups seek solutions to difficult problems, and both are not afraid to ask hard questions that challenge received wisdom. Yet, a potential alliance is not without its complications. The two groups' asymmetrical history could derail any thought of an alliance based on a shared will to combat climate change. Yet there is reason to contemplate the potential for cooperation between the ICC and the EU.

\section{Inuit Circumpolar Council and Arctic Development}

Founded in 1977, the Inuit Circumpolar Conference (now Council) is a trans-boundary organization representing the interest of Inuit from Canada, Alaska, Greenland, and Russia. Since its creation its primary objective has been to "preserve the Arctic environment and to create a comprehensive Arctic policy." 15 The Arctic scholar Jessica Shadian extols the ICCs political persistence and savvy media campaigns through which it has developed a role as an "influential political actor." 16

At its embryonic stage, Eben Hopson, founder of the ICC, wrote a letter to U.S. President Jimmy Carter, stating: "We hope that our Inuit Circumpolar Conference will initiate dialogue between the five Arctic coastal nations necessary to lead to formal agreements for safe and responsible oil and gas development." ${ }^{17}$ Although hydrocarbon development was thought to be problematic, it would bring heat to Inuit homes, which was a significant consideration. In 1981 an article in Foreign Affairs noted that "[ $t]$ ransarctic diplomacy was thus not pioneered by the six governments of the adjacent

13 Abdel Ghoneim, "Meeting the Challenges of Arctic Development," Offshore Magazine webcast (24 February 2011); available at: http://www.offshore-mag.com/index/webcasts/ webcast-display/1403483920/webcasts/webcasts-offshore/live-events/os-arctic.html.

14 Stephen Lacey, "After North Sea Oil Spill, Shell Plans to Continue Arctic Drilling," Grist (16 August 2011); available at http:/grist.org/fossil-fuels/2011-08-16-after-north-sea-oilspill-shell-plans-continue-arctic-drilling/.

15 Jessica Shadian, "Remaking Arctic Governance: The Construction of an Arctic Inuit Polity," Polar Record 42 (2006): 249-59.

16 Jessica Shadian, "From States to Polities: Reconceptualizing Sovereignty through Inuit Governance," European Journal of International Relations 16:3 (2010): 485-510.

17 Quoted in Shadian, "Remaking Arctic Governance." 
states," but rather by the efforts of the ICC. ${ }^{18}$ The formalization of trans-Arctic diplomacy took place with the founding of the Arctic Council in 1996.

In 2000, the ICC was also well positioned to influence the Arctic Council's Sustainable Development Framework. The guiding principles of the framework stipulate that sustainable development must include "opportunities to protect and enhance the environment and the economies, culture and health of indigenous communities and of other inhabitants of the Arctic." 19

When the Arctic Council's Arctic Climate Impact Assessment (ACIA) was ready for release, the United States attempted to delay it until an undisclosed date. Sheila Watt-Cloutier called on her Washington contacts to push the report forward. At her behest, Senators McCain, Lautenberg, and Snowe intervened, and the ACIA became public in November 2004 as originally planned. For the ICC, the ACIA was seen as a means to "bridge the gulf between European and American responses to global climate change." The ICC embraced the involvement of other non-Arctic states including the European Union, adding that the U.K. had been particularly involved in the work of the Arctic Council. ${ }^{20}$

Many in the Inuit community associate sustainability with the cultural and economic implications of Western domination. Whereas the historic processes of colonization created artificial boundaries and attempted to eradicate Inuit traditions and culture, Aqqaluk Lynge, now chair of the ICC, associates climate change with the historic "culture-changing" effects of missionaries and colonizers. ${ }^{21}$

The rejection of historic colonialism is also evident in the ICCs Circumpolar Inuit Declaration on Sovereignty in the Arctic. The Declaration underscores cooperation between Arctic nations and indigenous peoples. This was particularly significant in light of a 2008 meeting held by the Arctic coastal states: Canada, Denmark, Norway, Russia, and the United States.

Informally known as the Arctic 5, these states together wrote the Ilulissat Declaration in 2008, which appears to undermine the cooperative spirit of the Arctic Council. Brooks Yeager, former U.S. Assistant Secretary of State for Environment and Development, observed that the meeting might signify an attempt by the Arctic 5 to take a "predominant role" in Arctic decision-making. Yeager noted, "Such a view obviously

18 Lincoln P. Bloomfield, “The Arctic: Last Unmanaged Frontier," Foreign Affairs 60:1 (1981): 90 .

19 Arctic Council, Framework Document (Chapeau) for the Sustainable Development Programme (13 October 2000); available at http://arctic-council.org/section/documentation.

20 Sheila Watt-Cloutier, Climate Change and the Arctic: Bringing Inuit Perspectives to Global Attention, Inuit Circumpolar Council, Address to the Norwegian Research and Technology Forum in cooperation with the Carnegie Institution second Trans-Atlantic Cooperative Research Conference, "Meeting the Climate-Energy Challenge" (Washington, D.C., 5 October 2004); available at www.inuitcircumpolar.com/index.php?ID=271\&Lang=En.

21 Aqqaluk Lynge, "Strengthening Culture through Change: Will Climate Change Strengthen or Destroy Us?", Luncheon Address at the University of Edinburgh, Scotland (2009); available at www.inuit.org/index.php?id=280\&L=1. 
challenges the potential for either the non-coastal Arctic nations or non-Arctic governments to exert claims and interests in resources, or influence over their disposition." 22

Inuit, however, intend to exert their rights to all Arctic resources, some of which are protected under various international and domestic laws. While the Declaration on Sovereignty makes reference to natural resources, the 2011 Circumpolar Inuit Declaration on Resource Development Principles in Inuit Nuaat suggests that the ICC has assumed a conditionally aggressive approach to natural resource development, linked to Inuit governance and the socioeconomic benefits that would accrue to Inuit people. The 2011 Declaration states that development of non-renewable energy resources can contribute to "Inuit economic and social development through both private sector channels (employment, incomes, businesses) and public sector channels (revenues from publicly owned lands, tax revenues, infrastructure)."

Yet differing degrees of national autonomy coupled with variations in the foreseeable access to natural resources weakened the final outcome of the declaration on resources. Where leaders had wished to impose stronger limitations on resource development, disagreements on the extent of development led to a more flexible set of guiding principles. Influenced predominantly by Greenland's imminent access to potential hydrocarbon production, Greenlandic leaders view development as an opportunity to gain economic independence from Denmark. Premier Kuupik Kleist argued: "Companies from the outside have been exploiting natural resources in the Arctic area for centuries now. The Inuit didn't. Now it's our turn." ${ }^{23}$ Indeed, the great paradox of Inuit decision making sits at the nexus of environmental security and socioeconomic development.

\section{The European Union and Arctic Development}

When the European Union's Arctic policy comes to fruition, some believe its likely focus will emphasize climate change and environmental issues rather than energy security, which in some respects is aligned with ICC policy. ${ }^{24}$ Concurrently the EU has a strategic interest in acquiring Arctic resources. However, in a best-case scenario the EU could extend its climate change strategy to the Arctic, linking emission reductions to energy security and economic growth.

In 2009, the EU adopted binding legislation known as the "20-20-20" targets. As of 2009, total EU-27 GHG emissions have dropped 17.4 percent from 1990 levels, achieved in part through the development of renewable energies. However, unlike

22 Brooks B. Yeager, "The Ilulissat Declaration: Background and Implications for Arctic Governance," paper prepared for the Aspen Dialogue and Commission on Arctic Climate Change (5 November 2008).

23 Sarah Rogers, "Arctic Resource Development Inevitable and Safe: Greenland," Nunatsiakonline.ca (24 February 2011); available at http://www.nunatsiaqonline.ca/stories/article/ 240124_arctic_resource_development_inevitable_safe_greenland/.

24 Kristine Offerdal, "Arctic Energy and EU Policy: Arbitrary Interest in the Norwegian High North," Arctic 63:1 (2010): 30-42. 
Canada, for instance, the EU is a net energy importer, which renders the development of renewable energy resources relatively uncontroversial. "EU climate policy," notes Miranda Schreurs, "is seen as a way of moving member economies toward greater energy autonomy, resource efficiency, and technological progress." 25

Although support for the emissions reduction scheme is not unanimous, some nations such as the U.K. have been particularly aggressive in pursuing reductions in carbon emissions. In 2008, the U.K. Climate Change Act became the first legally binding climate change framework; the emissions reduction goal was set to 80 percent by 2050 . The policy received strong political and public support. Once a net supplier of oil and gas, the U.K. must now look to other sources for energy security, including renewable sources. ${ }^{26}$ Additionally, studies have shown that rising sea levels will impact environmental and economic security in the U.K. A 2010 U.K. Parliamentary Office of Science and Technology study estimated that there is GBP 120 billion worth of infrastructure and resources at risk from coastal flooding and a further GBP 10 billion at risk from coastal erosion. ${ }^{27}$ Beyond domestic and region-wide climate policy, the EU has a strategic interest in shaping strategies and policy pertaining to the Far North. Arno Behrens, an expert on the nexus of energy and climate change, notes: "Europe's transition towards a low-carbon energy system will only make sense in the context of global emissions reductions." 28

In the aftermath of the BP Deepwater Horizon disaster in 2010, the EU Parliamentary Committee on Industry, Research, and Energy passed a draft resolution calling for tougher environmental and safety standards on all offshore oil and gas drilling. ${ }^{29}$ According to Danish Maritime Magazine, if the legislation had passed in its entirety it would have temporarily halted all deep sea drilling in the Arctic. ${ }^{30}$ Instead, on 13 September 2011, Parliament adopted Facing the challenge of the safety of offshore oil and gas activities, which calls for tougher regulations on companies seeking a license for offshore exploration and exploitation licenses. In addition, industry should demonstrate

25 Miranda A. Schreurs, "Federalism and the Climate: Canada and the European Union," International Journal 66:1 (2010-11): 91-108.

26 Ibid.

27 United Kingdom Parliamentary Office of Science and Technology, “Sea Level Rise,” Postnote 363 (September 2010).

28 Arno Behrens, "The Role of Renewables in the Interaction Between Climate Change Policy and Energy Security in Europe," Renewable Energy Law and Policy Review 1 (2010): 5-15.

29 European Parliament, Committee on Industry, Research, and Energy, "Offshore Oil and Gas Drilling: Tougher Environment and Safety Standards Needed" (12 July 2011); available at www.europarl.europa.eu/en/pressroom/content/20110614IPR21329/html/Offshore-oil-andgas-drilling-tougher-environment-and-safety-standards-needed.

30 "EU Wants Deepwater Drilling in the Arctic Stopped," Danish Maritime Magazine (13 July 2011); available at www.danishmaritimemagazine.com/Nyheder/nyhed.aspx?NewsID $=13302$ \&Titel $=$ EU\%20wants\%20deepwater\%20drilling\%20in \%20the \%20Arctic\%20stopped. 
the ability to bear the full cost of clean-up and compensation in the event of a disaster either through insurance or industry mutualization. ${ }^{31}$

When the European Parliament adopted A Sustainable EU Policy for the High North in 2011, it advocated for "broad all-encompassing ecosystem-based approaches most likely to be capable of dealing with the multiple challenges facing the Arctic related to climate change." 32 However, at a parliamentary debate prior to the vote, one critic argued: "There seems to have been a very subtle shift ... in our thinking, towards security; security of energy supply and security of the use of resources." ${ }^{33}$ Indeed, confidential U.K. Foreign Office documents obtained by Greenpeace revealed that the U.K. was considering "how best to support" Shell and BP in Russia's Sakhalin-2 gas field project. The U.K. is the largest foreign investor in the Russian energy sector, and has expressed significant interest in Arctic drilling and shipping. ${ }^{34}$ Indeed, the EU's Arctic strategy lacks clarity, perhaps as a result of its tenuous position as it waits for a seat on the Arctic Council.

At present the EU is extolling the benefits of an UN Convention on the Law of the Sea (UNCLOS)-based Arctic governance system. Dr. Joe Borg, former EU Commissioner for Fisheries and Maritime Affairs, reasoned that the challenges and opportunities facing the Arctic were of a "truly global nature," and that "the keywords for the 21 st century international policy for the Arctic must be unity and cooperation." 35 By aligning their interests with UNCLOS, the EU seeks "to secure or enhance their status in the [Arctic] governance debate." 36

In terms of Arctic nations, upon ratification of UNCLOS, a country has ten years to make claims to an extended continental shelf which, if validated, gives it exclusive rights to resources on or below the seabed of that extended shelf area. However, UN-

31 European Parliament, "On facing the challenges of the safety of offshore oil and gas activities" (13 September 2011); available at www.europarl.europa.eu/sides/getDoc.do? pubRef=//EP//TEXT+TA+P7-TA-2011-0366+0+DOC+XML+V0//EN.

32 European Parliament, A Sustainable EU Policy for the High North (A7-0377/2010) (Strasbourg, 20 January 2011).

33 European Parliament, A Sustainable EU Policy for the High North (debate) (Strasbourg, 20 January 2011); available at www.europarl.europa.eu/sides/getDoc.do?pubRef=-//EP//TEXT $+\mathrm{CRE}+20110120+\mathrm{ITEM}-004+\mathrm{DOC}+\mathrm{XML}+\mathrm{V} 0 / / \mathrm{EN}$.

34 Greenpeace International, “U.K. Government Documents on Arctic Drilling," greenpeace.org (24 May 2011); available at www.greenpeace.org/international/en/publications/ reports/UK-Government-Documents-on-Arctic-Drilling/UK-Documents-on-Arctic-Drilling/ and www.greenpeace.org/international/en/publications/reports/UK-Government-Documentson-Arctic-Drilling/UK-Document-on-Arctic-Drilling/.

35 Joseph Borg, "The European Union's Strategy of Sustainable Management for the Arctic," speech given at the Arctic Frontiers Conference, Tromso, Norway (19 January 2009); available at: http://ec.europa.eu/maritimeaffairs/speeches/speech190109_en.html.

36 Timo Koivurova, "Protecting the Environment or Preventing Military Conflicts?: Policy Dynamics," Environmental Policy and Law 40:4 (2010): 170. 
CLOS applies to nations beyond the borders of Arctic states. ${ }^{37}$ In addition to acting as a mechanism regarding exclusive economic zones, UNCLOS includes freedom of the seas, and also classifies natural resources as belonging to "the common heritage of mankind" whereby no one state can exercise exclusive sovereignty over a given area. While UNCLOS has entered uncharted waters with the changing patterns of Arctic sea ice, Parker Clote suggests "UNCLOS is flexible, premised on balancing the customary freedom of the seas with the tendency of recidivist States to expand towards the high seas." 38

Both the Arctic Council and the United Nations will have a role to play in how Arctic strategy and governance develops in the region. Yet the direction in which the conversation tilts could determine the strength of each stakeholder's voice. Denmark's Foreign Minister Lene Espersen encouraged the Arctic 8 to fully support the Arctic Council so as to prevent it from turning into an "exclusive club." Failing to do so, she asserted, would risk creating a parallel Arctic forum at the UN, where Arctic nations "would not have a strong voice." 39

\section{Conclusion}

Is there potential for an ICC-EU alliance on climate change strategy? Yes, should each group decide to put aside their widely divergent histories of colonial practices in order to address the larger challenge: long-lasting environmental security. As we await a comprehensive international climate change agreement, transboundary associations such as the EU and ICC still constitute the best hope for producing creative solutions to global problems.

37 Michael Byers, “Cold Peace: Arctic Cooperation and Canadian Foreign Policy," International Journal (Autumn 2010): 899-912.

38 Parker Clote, "Implications of Global Warming on State Sovereignty and Arctic Resources under the United Nations Convention on the Law of the Sea: How the Arctic is no Longer communis omnium naturali jure," Richmond Journal of Global Law and Business 8 (2008): 195.

39 “New Strategy Outlines Denmark's Arctic Engagement," People's Daily Online (23 August 2011); available at http://english.peopledaily.com.cn/90777/90853/7577436.html. 


\section{Bibliography}

"New Strategy Outlines Denmark's Arctic Engagement." People's Daily Online (2011).

Behrens, Arno. "The Role of Renewables in the Interaction Between Climate Change Policy and Energy Security in Europe." Renewable Energy Law and Policy Review 1 (2010): 5-15.

Bloomfield, Lincoln P.. " The Arctic: Last Unmanaged Frontier." Foreign Affairs 60, no. 1 (2010).

Borg, Joseph. The European Union's Strategy of Sustainable Management for the Arctic In Arctic Frontiers Conference. Tromso, Norway, 2009.

Byers, Michael. "Cold Peace: Arctic Cooperation and Canadian Foreign Policy." International Journal (2010): 899-912.

Chung, Emily. "Arctic Permafrost Thaw Will Boost Carbon Emissions." CBC News: Technology and Science (2011).

Clote, Parker. "Implications of Global Warming on State Sovereignty and Arctic Resources under the United Nations Convention on the Law of the Sea: How the Arctic is no Longer communis omnium naturali jure." Richmond Journal of Global Law and Business 8 (2008).

Dalby, Simon. "Security and Ecology in the Age of Globalization." Environmental Change and Security Project Report 8 (2002).

European Commission, Climate Action: The EU Climate and Energy Package ., 2010.

Ghoneim, Abdel. "Meeting the Challenges of Arctic Development." Offshore Magazine web-cast (2011).

Lacey, Stephen. "After North Sea Oil Spill, Shell Plans to Continue Arctic Drilling." Grist (2011).

Lynch, Patrick. "Arctic Sea Ice Continues Decline, Hits 2nd-Lowest Level." NASA News Feature (2011).

Lynge, Aqqaluk. Strengthening Culture through Change: Will Climate Change Strengthen or Destroy Us., 2009.

Ma, Jianmin, Chongguo Tian, Roland Kallenborn, and Hayley Hung. "Revolatilization of Per-sistent Organic Pollutants in the Arctic Induced by Climate Change." Nature Climate Change 1, no. 5 (2011).

Offerdal, Kristine. "Arctic Energy and EU Policy: Arbitrary Interest in the Norwegian High North." Arctic 63:1 (200): 30-42.

Rogers, Sarah. "Arctic Resource Development Inevitable and Safe: Greenland." Nunatsia-konline.ca (2011). 


\section{THE QUARTERLY JOURNAL}

Schreurs, Miranda A.. "Federalism and the Climate: Canada and the European Union." International Journal 66:1 (2010).

Shadian, Jessica. "From States to Polities: Reconceptualizing Sovereignty through Inuit Governance." European Journal of International Relations 16, no. 3 (2010): 485-510.

Shadian, Jessica. "Remaking Arctic Governance: The Construction of an Arctic Inuit Polity." Polar Record 42 (2006): 249-59.

Stephenson, Scott R., Laurence C. Smith, and John A. Agnew. "Divergent Long-term Trajectories of Human Access to the Arctic." Nature Climate Change (2011): 156-60.

Watt-Cloutier, Sheila. Climate Change and the Arctic: Bringing Inuit Perspectives to Global Attention In Inuit Circumpolar Council, Address to the Norwegian Research and Technology Forum in cooperation with the Carnegie Institution second Trans-Atlantic Cooperative Research Conference, "Meeting the Climate-Energy Challenge. Washington, D.C, 2004.

Yeager, Brooks B.. "The Ilulissat Declaration: Background and Implications for Arctic Governance." In Aspen Dialogue and Commission on Arctic Climate Change., 2008. 